\title{
INTRODUCTION \\ Decolonization and Religion in the French Empire
}

\author{
Giuliana Chamedes \\ University of Wisconsin at Madison \\ Elizabeth A. Foster \\ Tufts University
}

In just two decades after the end of the Second World War, nearly all of Europe's colonies in Africa and Asia gained independence, in what one scholar has called "one of the most dramatic processes of political emancipation in world history." ${ }^{1}$ What prepared the ground for this far-reaching transformation? How did the decolonization of European empires shape international politics and the lived experience of European and non-European peoples? How did Christian, Muslim, Jewish, Buddhist, and other groups position themselves vis-à-vis these transformations, as they staked out transnational communities of allegiance and engaged in interdenominational debates and battles? Decolonization came at a critical historical juncture in religious matters: on the heels of the mass slaughter of European Jews; soon after the European mobilization of large numbers of Muslim colonial soldiers; and in the midst of "the hour of the Church" and the victory of Christian Democratic parties at the polls across much of Western Europe. Decolonization recast global relations just as the Cold War gained ground-a war in which the United States elevated itself as the defender of religion in general, and "JudeoChristianity" in particular. Did religious groups, mobilizing religious claims, have an impact on the collapse of European colonial empires? What role (if any) did they play in the rise of human rights and in reshaping understandings of humanitarianism and economic development within the framework of the United Nations? Conversely, how might religious groups have resisted decolonization, ignored it, or fostered neocolonial relationships of various 
sorts? How did decolonization itself, and the large-scale migrations that it engendered, transform religious communities and diasporic relations? Finally, how might it be analytically useful for historians to view the history of decolonization and religious histories as intertwined?

The essays in this special issue mobilize techniques of social, cultural, intellectual, and international history to grapple with these questions in the French imperial context. The recent fiftieth anniversaries of independence in French sub-Saharan Africa and Algeria have provoked a flurry of scholarly inquiry on decolonization in the French empire. At the same time, scholars across a variety of fields, including the diplomatic, cultural, and imperial history of modern Europe more broadly, have taken a new interest in religion, and the impacts of religious faith and religious institutions on a variety of cultural, social, and political processes. This is particularly significant in the case of modern France, where republican insistence on secularism has left a deep imprint on the historiography. In this volume, we have assembled contributions from scholars working at the intersection of religion and decolonization in a variety of locations and contexts in France and the French empire. Our goal is to present new ways of approaching decolonization, and to showcase the importance and relevance of religion as a subject of historical inquiry in the French case and more broadly. Doing so, we contend, provides a new perspective on what Martin Shipway has called "the late colonial shift," that is, on the change in the perceptions of colonizers and colonized regarding empire. ${ }^{2}$ It also shows us how significant-and insignificant-decolonization could be, in terms of its impact on a range of religious communities.

The resurgence of scholarly interest in modern France as a colonial empire, rather than simply as a nation-state, continues to thrive in its third decade. ${ }^{3}$ Moreover, many recent contributions to French colonial history examine how religion, particularly imported European faiths, shaped or contested colonial rule in a variety of contexts. It is notable that for a long time, many historians of late nineteenth- and twentieth-century France working on the colonies overlooked the important presence (and the rich archives) of Catholic and Protestant missionaries, who outnumbered colonial administrators on the ground throughout much of the empire. ${ }^{4}$ This blind spot reflects how profoundly the trope of republican secularism shaped the questions that historians of modern France were asking. It was also a consequence of a fixation on the colonial state itself, a fixation born of a desire to understand how a "republican" metropole justified and carried out colonial endeavors. Happily, a vibrant collection of new interventions is now illustrating the ways in which missionaries aided, questioned, and contested French colonial initiatives, and affected indigenous communities in the colonies. ${ }^{5}$ Examining the actions and impacts of these religious actors uncovers new realms of interaction between French and colonized peoples and provides much-needed perspective on the reach and the limitations of the colonial state. 
There are still many opportunities, moreover, to investigate how indigenous religious institutions and actors engaged with, contested, accommodated, or ignored the French presence in the colonies. In this domain, the bulk of the existing literature focuses on Islam, which, as scholars have shown, was also the subject of obsessive study by French colonial officials in North and West Africa. ${ }^{6}$ Some studies have illuminated brilliantly how Muslim subjects and citizens understood, challenged, negotiated, and endorsed French colonial rule in the nineteenth and twentieth centuries. ${ }^{7}$ To the limited extent that scholars have examined decolonization and religion together in the French context, they have tended to focus on the role of Islamic parties and institutions in the Algerian war. ${ }^{8}$ Recent studies have also focused on how the French state approached its increasing metropolitan population of Muslims before and after the independence of the North and West African colonies. These have helped to puncture the idea that secularism, or laïcité, was a basic tenet of a universal French republicanism, showing instead how it was a product of constant renegotiation, and often a placeholder for racism. ${ }^{9}$

The essays in this special issue focus attention on understudied religious groups in Cameroon, Vietnam, Algeria, and France itself. They temper-and in some cases, upend-simplistic visions of European religions as mere tools of colonialists or of indigenous faiths as instruments of revolt against French rule. The goal is not to uncover religious underpinnings of procolonial and anticolonial politics. Some of the essays collected here speak to political aspects of decolonization, but that is not the raison d'être of this special issue. Rather, the essays explore the rich, textured life of religious communities, the shaping of transnational discursive frameworks by religious actors, and the enduring power of religion in what scholars once termed "the age of secularization."

Indeed, just as we take an expansive view of religion, we argue that decolonization should be understood in a broad sense as a complex process of disentangling societies, a process that takes place in social, economic, and cultural realms, as well as in the political and diplomatic sphere. The historiography of decolonization was long dominated by state-centered inquiries and political histories of the transitions from European colonial rule to successor nation-states. This approach fit the hegemonic logic of nationhood: for example, after independence, historians of Africa celebrated the achievements of national liberators, and mined the historical record for the roots of the nation. ${ }^{10}$ Emerging scholarship on France and Africa is cracking this edifice by showing how nation-states were not necessarily the outcomes imagined or sought by many prominent actors in the 1950s and 1960s. ${ }^{11}$ Yet much of the literature has failed to examine decolonization outside the narrow boundaries of state actors and political parties. Moreover, stories of national awakenings and new beginnings tended to emphasize the ruptures and changes of decolonization, obscuring important continuities.

In former colonies, we argue, decolonization meant withdrawing or rebalancing European personnel, ideas, influence, and financing across a range of 
settings and institutions, both public and private. In some realms, withdrawals were thoroughgoing, in others merely cosmetic. And of course, in some domains European influence had always been very limited. At the same time, as Todd Shepard and Kristin Ross have shown in the French case, decolonization changed policies, attitudes, narratives, and popular culture in the metropole. ${ }^{12}$ The essays in this special issue are all contributions to French history, but at the same time they move beyond national or political frameworks. In the process, they address questions like the following: Did decolonization fundamentally alter patterns of social allegiance and encourage the forging of new ties, be they national or transnational? Conversely, has the importance of decolonization been over-emphasized? In certain domains of intellectual, cultural, and social life, did decolonization have little perceivable impact on language and practice-or even none at all?

The contributors to this collection offer varied answers to these crucial questions. For Pascal Bourdeaux, Naomi Davidson, and Giuliana Chamedes, the Algerian War and the First War in Indochina did not fundamentally alter certain core dispositions, agendas, and social developments. Overall, the stories they tell tend to emphasize continuity over discontinuity. For example, Naomi Davidson reminds us that post-independence relations between Algerian and French Jews remained in line with much that had transpired in the period prior to 1962. French Jews continued to view France's cultural heritage and French Jewish religious rites as 'more civilized' and 'less backwards' than those of their Algerian counterparts. During and after the war, French Jews assumed that Algerian Jews saw France as their natural home; this assumption vastly oversimplified Algerian Jews' complex sense of self. Algerian Jews (or, more precisely, northern Algerian Jews) had gained French citizenship through the Crémieux decree of 1870, which excluded Muslim Arabs and Berbers and hardened the divide between ethnic and religious groups in the territory. (As Sarah Stein has noted, the decree was exceptional for two reasons: it was one of the "only acts of mass naturalisation to occur under modern European imperial rule," and it was the only instance "in the colonial world in which autochthonous Jews were granted citizenship by a colonial power."13) But the Crémieux decree notwithstanding, Algerian Jews remained torn between their Algerian heritage, their legal status as French citizens, and their allegiance to North African Jewish rituals, beliefs, and practices. As Davidson shows, these tensions were manifest at the political level as well, as both the FLN and the OAS expected Algerian Jews to take their side. Despite pragmatic declarations of allegiance to France, many Algerian Jews remained deeply conflicted-and those who left Algeria for France saw the migration as a form of exile, or even as a tragedy, rather than as a return 'home'. ${ }^{14}$

But Davidson's contribution is not solely focused on the question of identity and inter-Jewish perceptions. She also highlights how the French state chose to manage religious life following the Algerian War. Arguing against certain historiographical assumptions, Davidson suggests that in the case of inter- 
Jewish relations, the French state reinforced preexisting divisions between French and Algerian Jews, rather than promoting an assimilationist or 'integrationist' agenda. Building on her earlier research on the essentialization of Islam by the modern French state-which went along with the state's bureaucratic reduction of Muslim North African migrants to the status of "only Muslim"-Davidson shows that a similar story unfolded in the case of North African Jews. ${ }^{15}$ In the aftermath of the Algerian War, the French Consistory, which since 1919 had been under the jurisdiction of the French state, mandated the creation of 'separate but equal' religious services for North African and French Jews. Reifying the distinction between western and non-western, and between 'Ashkenazi' and 'Sephardic,' the French state thus pursued an anti-integrationist agenda-as it did, more broadly, with Muslim-majority immigrants moving to France in increasing numbers. As Todd Shepard and others have argued, the French state may well have pursued a policy of 'integration' in its attempt to keep Algeria within its orbit of influence; however, as Davidson's research suggests, this was not the case when it came to religious questions, whether for Algerian Jews or North African Muslims. ${ }^{16}$ In this sense, she makes a double case for continuity: continuity in how French Jews perceived Algerian Jews, and continuity in how the French state sought to keep Algerian Jews 'separate but equal'.

Similarly, in his compendious analysis of Vietnamese religious cultures, Pascal Bourdeaux actively resists the tendency to cast the decolonization of Indochina/Vietnam as a game-changing event for communities on the ground. Bourdeaux demonstrates that many of the most striking religious and social transformations were underway long before the wars of independence. Further, Bourdeaux emphasizes that it is historically inaccurate to view religion as a tool of the Cold War, or a western instrument for the country's subjugation. Rather, the rich patchwork of religions in Indochina/Vietnam matter because they mobilized the deep personal convictions of large swaths of the population. In his nuanced picture of religious life in Indochina/Vietnam, Bourdeaux illustrates the long history of trends such as the indigenization of the clergy, the rise of Protestant missionary activism, and the emergence of syncretic and mystical variants of Buddhism, Taoism, and Confucianism. He also explores how religious traditions were internally divided when it came to their stance on politics and decolonization: some favored the idea of thrusting religion into the public sphere, and using its claims to buttress anti-imperial appeals, while others preferred to present religion as a matter of private conscience or purely spiritual devotion. Catholicism is a case in point. As Bourdeaux demonstrates, proindependence, proempire, and "apolitical" Catholic groups debated the proper place of religion vis-à-vis the state throughout the course of the 1940s and beyond. Thus, there was nothing preordained about the relationship between religion and the state that emerged in post-independence Indochina/Vietnam. Matters might well have turned out otherwise had the debates within and across these very diverse religious groups and traditions gone differently. 
In her examination of the Dominican economist Father Louis-Joseph Lebret, Giuliana Chamedes also emphasizes continuity instead of rupture at the end of empire. Stressing the importance of long-overlooked Catholic contributions to the elaboration of the concept of economic development in the postwar period, Chamedes situates Lebret's thinking in the Cold War context of Catholic (and European) uneasiness about American influence and concurrent fears of Soviet communism. Lebret and his followers expounded a "third way" that rejected both the American and Soviet models in its efforts to help poor and disadvantaged countries achieve economic growth. Lebret became an advocate for an end to formal French empire, but he saw no need to dial back French influence in its former colonies and the wider world. His thinking was rooted in an older French Catholic missionary ethos: he believed that Catholicism was a superior faith. As Chamedes puts it, he and his followers conceived of France as a "standard-bearer" of civilization, which could and should play an outsized role on the world stage, colonies or no. Crucially, her analysis also shows that Lebret's thought, while a response to particular French preoccupations, traveled far afield into international institutions and before a wide variety of audiences around the globe. Like Charlotte Walker-Said's article (discussed below), Chamedes' essay demonstrates how international agencies were important actors in the decolonizing world, and served as fora where both imperial powers and colonial subjects aired their claims and made appeals across political boundaries. ${ }^{17}$

Where Davidson, Bourdeaux, and Chamedes see continuity with regard to interreligious and intrareligious matters, Charlotte Walker-Said and Darcie Fontaine make a case for discontinuity. Walker-Said focuses on the contest between competing visions of the proper aims and scope of humanitarian assistance, as debated in Cameroon in the contentious decade prior to independence. The conflict-which spanned the 1950s, and developed, on WalkerSaid's reading, in response to the prospect of decolonization-pitted African Church leaders and local charities against high-ranking European clergy and western missionary societies. The issue was not only about how to improve social blights like poverty, crime, and poor public health. More fundamentally, it concerned broad theoretical questions, viz., what constitutes 'society' and the appropriate scope of social assistance, both within local communities and on a global scale.

Drawing on little-tapped material consulted in France and Cameroon, Walker-Said highlights two rather surprising developments. First, she argues that decolonization helped transform the way European clergy discussed humanitarianism. Increasingly, European clergy began to refer to liberal, secular tropes, displacing older (religious) conceptions, in an effort to buoy the faith and justify the West's continued role on the African continent. Casting doubt on the "moral steadfastness and spiritual earnestness" of Cameroon's African Christians, European religious groups of the 1950s claimed that western intervention was the only way to protect vulnerable elements in African 
societies. They held that the human rights protections accorded by international law and the innovations of modern science could ameliorate the lot of African subjects, but only through the active involvement of western powers, groups, and individuals. The second key contribution of Walker-Said's essay regards how Cameroon's Christians responded to the changing rhetoric of European Christians. She demonstrates how African Christians took up the defense of an explicitly religious conception of humanitarian assistance and broadcast it in those same international fora used by European Christians. Speaking directly to members of UNESCO, UNICEF, WHO, and others, Cameroon's Christians made a powerful case for the success of local, neighborly, and religious forms of assistance and mutual aid. For these actors, this rebuke of the shift in western humanitarian rhetoric was part and parcel of their participation in the independence struggle, and an attempt to ward off heavy-handed western intervention in postimperial societies. On this reading, recently evangelized Africans appealed to religious traditionalism in the course of undertaking revolutionary anti-imperialist activism, while the defenders of the European Christian order paradoxically shed religious claims so as to maintain leadership in non-western settings. This provocative and far-reaching argument suggests a need to revisit much of the literature on the history of humanitarianism, Christian third-worldism, and the role of local and religiously based appeals in the struggle for independence in Africa and beyond.

In her article on the Algerian War and its immediate aftermath, Darcie Fontaine similarly argues that decolonization deeply altered inter-Christian languages and practices, in both France and Algeria. Her findings trouble much of our received knowledge: they indicate that certain European Catholics-despite their association with the French colonial project-played an active role in the construction of postcolonial Algeria. They did so by undertaking a successful attempt to distance themselves from proimperial sectors in the Church, courting Algeria's new leaders, and advertising the supposed anticolonial credentials of the Roman Catholic Church. Fontaine's story goes against the grain in another sense as well: these European Catholics worked from within Algeria rather than from France. While the historiography has tended to suggest that all pieds-noirs fled Algeria with the coming of independence, this was not in fact the case; between 200,000 and 300,000 European settlers remained in situ. About 89,000 of them were Catholics. And among these 89,000 , a large number sought to align themselves with the nascent Algerian state-not so much for pragmatic reasons, Fontaine suggests, but out of religious conviction.

To be sure, the Catholic stance on decolonization in postcolonial Algeria was far from uniform, and stark divisions risked splitting the community in two. Certain Catholics among the so-called pieds-verts (i.e., Europeans who remained in Algeria) were troubled by the arrival of firebrand left-wing Catholics after the war. Many of these new arrivals were sympathetic to Algeria's nascent socialist experiment and saw themselves as reversing the legacy of 
European imperialism through their charitable activities and their contributions to postwar reconstruction. They advocated policies that appeared radical and untenable to many Catholic pieds-verts and to high-ranking members of the Catholic clergy, such as the restitution of all mosques converted to Catholic churches following the French conquest of 1830. On the other side of this debate were those pieds-verts committed to recasting Catholicism as a religion that favored decolonization and ecumenism. A key figure in Fontaine's account is the Archbishop of Algiers, Monsignor Léon-Etienne Duval. Duval was a high-ranking member of the Catholic clergy sympathetic to socialism and to the project of radically reinventing the image of the Catholic Church in post-independence Algeria. Predictably, he won friends, and enemies as well. But as Fontaine demonstrates, it was thanks to the outspokenness of figures like Duval that the Catholic Church did not simply disappear with the coming of Algerian independence, as all too many historical accounts have suggested. Rather, this leader-who went on to become an active participant in Vatican II-represented an emergent strand within Catholicism in the early 1960s: one that was anti-imperialist, and keenly attuned to the challenges of missionary work in Catholic-minority contexts. One wonders whether Duval was himself in the grips of a romanticized third-worldism that celebrated and exoticized non-western revolutionaries-or whether his firm grounding in Algeria gave him a perspective that many European and American "revolutionaries" lacked. Fontaine's story suggests that if in some contexts European Christian leaders stuck to their imperial commitments (as was the case in Cameroon), this was not true everywhere.

Taken together, these five essays suggest the rich possibilities for historians at the intersection of religion and decolonization. We see this collection as a starting point for more comprehensive exploration of how decolonization transformed (or did not transform) philosophical, legal, and economic debates; how it altered everyday life in the colonies and the metropole; and how it shaped national and transnational interdenominational, cross-class, and North-South relations. At the same time, these essays provide a variety of models of how to incorporate religion into several historiographical approaches. In modern French history, religion often conjures up visions of reactionary, antirepublican Catholics, or struggling Muslim immigrants and their descendants. By contrast, this collection stresses the variety and subtlety of religious histories at a time of both uncoupling and forging new connections between France and its formerly subject peoples.

Giuliana Chamedes is Assistant Professor of History at the University of Wisconsin-Madison. She is a historian of modern European and international history with a particular interest in the internationalization of anticommunism and political Christianity after World War I. Her publications include "The Vatican, Nazi-Fascism, and the Making of Transnational Anticommunism in the 1930s," The Journal of Contemporary History (forthcoming), "The Vatican 
and the Reshaping of the European International Order after World War I," The Historical Journal (December 2013), and "Pius XII, Rights Talk and the Dawn of the Religious Cold War," in Religion and Human Rights, ed. Devin Pendas (Routledge, forthcoming).

Elizabeth A. Foster is Assistant Professor of History at Tufts University. She received her Ph.D. in history from Princeton University in 2006. Her first book, Faith in Empire: Religion, Politics, and Colonial Rule in French Senegal 1880-1940 (2013) won the Alf Andrew Heggoy Prize of the French Colonial Historical Society. She is currently working on a book length project tentatively entitled Decolonizing Faith: Catholics and the End of French Empire in SubSaharan Africa.

\section{Notes}

1. Jan Eckel, "Human Rights and Decolonization: New Perspectives and Open Questions," Humanity, 10 June 2014.

2. Martin Shipway, Decolonization and Its Impact: A Comparative Approach to the End of the Colonial Empires (Oxford: Wiley-Blackwell, 2008).

3. On the surge in French colonial history see Alice L. Conklin and Julia ClancySmith, "Introduction: Writing Colonial Histories," French Historical Studies 27 (2004): 497-505.

4. See estimates on French Catholic workers abroad ca. 1900 in J. P. Daughton, An Empire Divided: Religion, Republicanism, and the Making of French Colonialism, 1880-1914 (Oxford: Oxford University Press, 2006), 11.

5. Recent book-length examples dealing with the nineteenth and twentieth centuries include Daughton, An Empire Divided; Kenneth Orosz, Religious Conflict and the Evolution of Language Policy in German and French Cameroon, 1885-1939 (New York: Peter Lang, 2008); Sarah A. Curtis, Civilizing Habits: Women Missionaries and the Revival of French Empire (Oxford: Oxford University Press, 2010); J. P. Daughton and Owen White, eds., In God's Empire: French Missionaries and the Modern World (Oxford: Oxford University Press, 2012); Charles Keith, Catholic Vietnam: A Church from Empire to Nation (Berkeley: University of California Press, 2012); Elizabeth A. Foster, Faith in Empire: Religion, Politics and Colonial Rule in French Senegal, 1880-1940 (Stanford: Stanford University Press, 2013).

6. See, for example, Christopher Harrison, France and Islam in West Africa, 1860-1960 (Cambridge: Cambridge University Press, 1988); George R. Trumbull, IV, An Empire of Facts: Colonial Power, Cultural Knowledge, and Islam in Algeria, 1870-1914 (Cambridge: Cambridge University Press, 2009); and Edmund Burke III, The Ethnographic State: France and the Invention of Moroccan Islam (Berkeley: University of California Press, 2014).

7. Examples include Julia A. Clancy-Smith, Rebel and Saint: Muslim Notables, Populist Protest, Colonial Encounters (Algeria and Tunisia 1800-1904) (Berkeley: University of California Press, 1994); David Robinson, Paths of Accommodation: Muslim Societies 
and French Colonial Authorities in Senegal and Mauritania, 1880-1920 (Athens, OH: Ohio University Press, 2000).

8. See, for example, Omar Carlier, Entre nation et djihad: Histoire sociale des radicalismes algériens (Paris: Presses de la Fondation nationale des sciences politiques, 1995); James McDougall, History and the Culture of Nationalism in Algeria (Cambridge: Cambridge University Press, 2008).

9. See Joan Wallach Scott, The Politics of the Veil (Princeton: Princeton University Press, 2010); Naomi Davidson, Only Muslim: Embodying Islam in Twentieth Century France (Ithaca: Cornell University Press, 2012); Mayanthi Fernando, The Republic Unsettled: Muslim French and the Contradictions of Secularism (Durham: Duke University Press, 2014).

10. For a discussion of this phenomenon in the African case see Frederick Cooper, "Conflict and Connection: Rethinking Colonial African History," American Historical Review 99 (1994): 1516-45.

11. See Frederick Cooper, Citizenship Between Empire and Nation: Remaking France and Africa, 1945-1960 (Princeton: Princeton University Press, 2014); Gregory Mann, From Empires to NGOs in the West African Sahel: The Road to Nongovernmentality (Cambridge: Cambridge University Press, 2015); Gary Wilder, Freedom Time: Negritude, Decolonization and the Future of the World (Durham: Duke University Press, 2015).

12. Kristin Ross, Fast Cars, Clean Bodies: Decolonization and the Reordering of French Culture (Cambridge, MA: MIT Press, 1995); Todd Shepard, The Invention of Decolonization: The Algerian War and the Remaking of France (Ithaca: Cornell University Press, 2006).

13. Sarah Abrevaya Stein, "Dividing South from North: French Colonialism, Jews, and the Algerian Sahara," Journal of African Studies 17, 5 (December 2012): 773-92.

14. Benjamin Stora, La Gangrène et l'Oubli: La mémoire de la guerre d'Algérie (Paris: Éditions La Découverte, 1991).

15. Davidson, Only Muslim.

16. Todd Shepard, "À l'heure des 'grands ensembles' et de la guerre d'Algérie: L'Étatnation' en question," Monde(s). Revue d'histoire transnationale 1 (2012); and his "Algeria, France, Mexico, UNESCO: A Transnational History of Anti-Racism and Empire, 1932-1962," Journal of Global History 6, 2 (2011): 273-97.

17. On the interplay between the French Empire and international agencies see also Shepard, "Algeria, France, Mexico, UNESCO" and Jessica Pearson-Patel, "From the Civilizing Mission to International Development: France, the United Nations, and the Politics of Family Health in Postwar Africa, 1940-1960" (Ph.D. Dissertation, New York University, 2013). 